\title{
The Effect of the Promotion of Clean and Healthy Lifestyle in Ujong Tanjung Elementary School Through the SAL (Snake and Ladder) Media
}

\author{
${ }^{1}$ Susy Sriwahyuni, ${ }^{1}$ Zakiyuddin, ${ }^{1}$ Muhammad Reza Firdaus \\ ${ }^{1}$ Faculty of Public Health, Universitas Teuku Umar, Aceh, Indonesia \\ Coresponding author: Susy Sriwahyuni, e-mail: susysriwahyuni@utu.ac.id \\ Co-author: ZZ: zakiyuddin@utu.ac.id, MRF: mrezafirds@gmail.com \\ Submitted:20/03/2021 Revised:25/03/2021 Accepted:10/04/2021 Published online: 16/04/2021
}

doi: https://doi.org/10.35308/j-kesmas.v7i2.1646. How to cite this article: Sriwahyuni, S., Zakiyuddin, Z., \& Firdaus, M.R. (2021). The Effect of the Promotion of Clean and Healthy Lifestyle Behaviors in Ujong Tanjung Elementary School Through the SAL (Snake and Ladder) Media. J-Kesmas: Jurnal Fakultas Kesehatan Masyarakat (The Indonesian Journal of Public Health). 8(1): 41-44.

\begin{abstract}
School age children are groups that is prone to experiencing health problems due to low knowledge of clean and healthy lifestyle. To increase their knowledge, an attractive promotional media namely snake and ladder is needed so that the delivery of material is easily accepted by them. The purpose of this method is as a stimulus medium so that elementary school students can easily understand on how to improve clean and healthy life lifestyle. The research method was quasi-experimental with OneGroup Pretest-Posttest Design. The population were 85 elementary school students of Ujong Tanjung in IV, V and VI grade who had been given an understanding of CHL. The sample consisted of 30 persons who would be given a pre-test and post-test who were previously given snake and ladder media intervention. The results showed that there was a significant increase in knowledge after the intervention with snack and ladder media where during the pre-test the informants who had good knowledge were 11 persons $(36.7 \%$ ) but after being given the intervention there was an increase to 22 persons (73.3\%). While informants with poor knowledge category at the time of pre-test were 19 persons $(63.3 \%)$ after being given the intervention, there was a decrease to 8 persons (26.7\%). The Wilcoxon test results show the value of p-value $=0.000<\alpha=0.05$, so there is a difference in the level of informants' knowledge about CLHB (Clean and Healthy Living Behaviour) before and after the intervention using Snack and Ladder (SAL) media. The conclusion is that there are differences in the level of informants' knowledge about CLHB (Clean and Healthy Living Behaviour) before and after the intervention using Snack and Ladder (SAL) media.
\end{abstract}

Keywords: CLHB; Elementary School Student; Snake and Ladder (SAL).

\section{Introduction}

Health promotion is a form of intervention that is carried out to individuals, groups, or communities to have a positive influence on maintaining and improving their health (Notoatmodjo, 2014). The data of World Health Organization (WHO) stated there are more than one billion cases of gastroenteritis or diarrhea every year. The five provinces with diarrhea cases ranging from the lowest were West Sumatra as much as $29.0 \%$, Papua as much as $29.5 \%$, South Kalimantan as much as $32.3 \%$, North Sumatra as much as $32.9 \%$, and Aceh as much as $33.6 \%$ (Riskesdas, 2013). Basic Health Research (Riskesdas) showed Aceh residents aged $\geq 10$ years who wash their hands properly in 2013 was (38\%) and in 2018 was (36\%) (Riskesdas, 2018). In West Aceh District, the incidence of diarrhea in 2017 were 212 while in 2018 were 345 persons (Puskesmas Meureubo, 2019)

School-age children are groups that is prone to experiencing diarrhea due to low knowledge of clean and healthy life lifestyles. According to a preliminary survey in West Aceh District, Specifically at Ujong Tanjung elementary school, it was found that out of 10 students interviewed, 8 students still had poor knowledge on how to wash their hands properly. Therefore, health education is very important for students, because at this age children will learn directly from an environment such as a school environment. This lifestyle will make children more responsive to CHL while at school (Lina, 2017).

School-age children, especially elementary school student around 7-12 years is a golden time to inculcate the values of CHL. They are potential to become agents of change in promoting health for their surrounding environment. This can make CHL as a positive habit that is cultured in the community (Abidah \& Huda, 2018).

CHL in schools is a series of efforts carried out by school residents based on awareness to prevent disease, create a clean and healthy environment, and 
improve health. For the delivery of the material to be easily accepted by students, it is necessary to convey the material in a way that attracts students' interest (Supriyono, 2019).

One of them is through the game of snake and ladder as a medium to promoting clean and healthy lifestyle for elementary school students. The purpose is as a stimulus medium so that elementary school students can easily understand on how to improve clean and healthy lifestyle. The benefits of implementing this method for schools is the adoption of a clean and healthy lifestyle (CHL) in the school environment which can create a clean and healthy learning and school atmosphere. Therefore we are interested in conducting research "The Effect of the Promotion of a Clean and Healthy Lifestyle in Ujong Tanjung Elementary School Through the SAL (Snake And Ladder) Media.

\section{Methods}

The method used in this research is quasiexperimental. The design planned was One-Group Pretest-Posttest design. The population of this studied were students of SDN Ujong Tanjung grades IV, V and VI who had been given an understanding of CHL as many as 85 persons. The sample in this study consisted of 30 persons who would be given a pre-test and post-test who were previously given snake and ladder media intervention. The research design is described in the following schema:

$$
\mathrm{E}: \mathrm{O}_{1} \longrightarrow \mathrm{X}_{\mathrm{i}} \longrightarrow \mathrm{O}_{2}
$$

\section{Information:}

E : Snake and Ladder intervention group

$\mathrm{O}_{1}$ : Observers in the intervention group

$\mathrm{O}_{2} \quad$ : Second observer in the intervention group

$\mathrm{X}_{\mathrm{i}} \quad$ : Intervention

This research was directed at SDN Ujong Tanjung, West Aceh Regency on 16-26 September 2020. Data were analyzed using Univariate and Bivariate analysis with the Wicoxon Test. The research implementation has received Health Research Eligible Approval from the Health Research Ethics Commission of the Faculty of Nursing, University of North Sumatra with letter number: 2240 / IX / SP / 2020.

\section{Characteristics of Informants}

From the results has been carried out with total sample of 30 informants, it was found as follows:

Tabel 1. Informant Frequency Distribution based on Informant Characteristics $(\mathrm{n}=30)$

\begin{tabular}{lcc}
\hline Characteristic & Frequency & $\begin{array}{c}\text { Percentage } \\
(\%)\end{array}$ \\
\hline Gender & 17 & 56,7 \\
Male & 13 & 43,3 \\
Female & & \\
Grade & 8 & 26,7 \\
IV(Four) & 10 & 33,3 \\
V (Five) & 12 & 40 \\
VI (Six) & & \\
Age & 4 & 13,3 \\
9 & 5 & 16,7 \\
10 & 8 & 26,7 \\
11 & 10 & 33,3 \\
12 & 3 & 10 \\
13 & Source : Primary Data (Processed in 2020)
\end{tabular}

Based on Table 1, it was found informants with male gender were $17(56.7 \%)$ and 13 informants with female gender $(43.3 \%)$. Most informants were from VI (six) grade as many as 12 informants $(40 \%)$ and the least informants were from IV (four) grade consisted of 8 informants $(26.7 \%)$. Informants who were at most 12 years old were 10 informants $(33.3 \%)$ and at least 13 years old were 3 informants (10\%).

\section{Univariate Analysis}

After completing the pre-test, the results of the informants' knowledge were categorized based on the mean (average) value, as follows:

Tabel 2. Informants Frequency Distribution Based on PreTest Snake And Ladder (SAL) Media (n-30)

\begin{tabular}{lcc}
\hline Knowledge & Frequency & $\begin{array}{c}\text { Persentage } \\
(\boldsymbol{\%})\end{array}$ \\
\hline Good & 11 & 36,7 \\
Poor & 19 & 63,3 \\
\hline
\end{tabular}

Source : Primary data (Processed in 2020)

Based on table 2, it is known that informants with well knowledge were 11 informants (36.7\%), while informants with poor knowledge were 19 informants $(63.3 \%)$.

Tabel 3. Informants Frequency Distribution Based on Post Test Snake And Ladder (SAL) $(\mathrm{n}=30)$

\section{Results}




\begin{tabular}{lcc}
\hline Knowledge & Frequency & $\begin{array}{c}\text { Percentage } \\
(\boldsymbol{\%})\end{array}$ \\
\hline Good & 22 & 73,3 \\
Poor & 8 & 26,7 \\
\hline
\end{tabular}

Based on table 3, it is known that informants with well knowledge were 22 informants $(73.3 \%)$, while informants with poor knowledge were 8 informants $(26.7 \%)$.

Source : Primary data (Processed in 2020)

\section{Bivariate Analysis}

\section{Wilcoxon Test Results}

Tabel 4. Test of the Effect of Snack and Ladder (SAL) Media on Knowledge Improvement of Informants in Pre-test and Posttest (Wilcoxon Test) $(\mathrm{n}=30)$

\begin{tabular}{llcccc}
\hline & N & $\begin{array}{c}\text { Mean } \\
\text { Ranks }\end{array}$ & $\begin{array}{c}\text { Sum } \\
\text { Ranks }\end{array}$ & Nilai P \\
\hline Pretest Media SAL & Negative Ranks & 0 & 0,00 & 0,00 & \\
Post Test Media SAL & Positive Ranks & 29 & 15,00 & 435,00 & 0,000 \\
& Ties & 1 & 1 & & \\
& Total & $\mathbf{3 0}$ & & & \\
\hline
\end{tabular}

Source : Primary data (Processed in 2020)

Based on table 4, the Test of the Effect of Snack and Ladder (SAL) Media on the Pre-test and Post-test (Wilcoxon Test) Informants' Knowledge Enhancement the results are:

\section{Negative ranks or difference}

Between the results of the Snake and Ladder (SAL) media approach to increasing the informant's knowledge for the pre-test and post test is 0 , on the value of N, Mean Rank, and Sum Rank. This value of 0 indicates that there is no decrease (reduction) from the pre-test to the post-test results.

\section{Positive ranks atau difference (positive)}

Between the results of the Snake And Ladder (SAL) media approach to increasing the informant's knowledge for the pre-test and post-test, there is a positive data $(\mathrm{N})$ of 29 , which means that 29 informants experienced an increase in knowledge from pre-test results to post-test results. The mean rank or the average increase is 15.00 while the number of positive ranks or the sum of the ranks is 435.00

\section{Ties or similarities in pre-test and post-test result}

Based on table 4 above, it is known that the value of ties is 1 , which means that there is a similarity in the value of the pre-test and post-test.

Based on the results of the output test statistics above, it is known that Pvalue $=0.000<\alpha=0.05$, it can be concluded that there are differences in the level of informants' knowledge about CHL (Clean and Healthy Life Lifestyle) before and after giving intervention through Snack and Ladder (SAL) media

\section{Discussion}

Based on the results of the study, there was a significant improvement in knowledge after the intervention with snake and ladder media where during the pre-test the informants who had good knowledge were 11 persons $(36.7 \%)$ but after being given the intervention, it was increase into 22 persons $(73.3 \%)$. While informants with poor knowledge category at the time of pre-test were 19 persons $(63.3 \%)$ after being given the intervention, it was decrease into 8 pe $(26.7 \%)$. Based on the results of the Wilcoxon test, the Pvalue $0,000<\alpha=0.05$, so that there is a difference in the level of informants' knowledge about CHL (Clean and Healthy Live Lifestyle) before and after giving intervention through Snake and Ladder (SAL) media.

The snake and ladder media has advantages in increasing students' knowledge because this media is more attractive and can be applied in playing while learning activities so that it helps students hone their logical intelligence and stimulate their cognitive in solving problems. This research is same with Prasetyanti \& Yanuaringsih (2019) research that there is an effect of snake and ladder game on lifestyle in CHL with Pvalue $=0.002<\alpha=0.05$.

Another study directed by Hamdalah (2013) stated that snake and ladder media have a higher effectiveness than pictorial story media in perceiving knowledge, attitudes, and practices about oral health. This research is supported from Sari (2016) that there is an effect of health education on hand washing through snake and ladder media on increasing knowledge of preschoolers at TK ABA Karangbendo and TK Pertiwi 21 Babadan Banguntapan Bantul. 
Furthermore, research directed by Nurhidayati \& Hilal (2018) states that there is an effect of health education on PHBS with the snake and ladder game media. Research directed by Hadisuyitno et al (2017) shows that there are significant differences in the level of knowledge before and after counseling with the game of snake and ladder. The learning method using snake and ladder media is an effective intervention to increase children's health knowledge (K.Srinivasan, 2019).

\section{Conclusion}

The conclusion of this study is that there are differences in the level of respondents' knowledge about CHL(Clean and Healthy Lifestyle) before and after giving intervention through the media of Snack And Ladder (SAL) $($ Pvalue $=0.000<\alpha=0.05)$.

\section{Acknowledgement}

Thank you to SDN Ujong Tanjung, both the Principal, Teachers and Students who have participated so enthusiastically that this research can be completed on time

\section{Author Contribution and Competing Interest}

All of the authors contributed in collecting and analyzing the data, including preparing the manuscript. The author assures there is no conflict of interest in the activities and preparation of this report.

\section{Publisher's Note}

J-Kesmas: JurnalFakultas Kesehatan Masyarakat (Indonesia Journal of Public Health) remains neutral with regard to jurisdictional claims in published institutional affiliation.

\section{References}

Abidah, Y. N., \& Huda, A. (2018). Pelaksanaan Program Perilaku Hidup Bersih Dan Sehat (PHBS) Di Sekolah Luar Biasa. Jurnal Ortopedagogia, 4(2): 87-93.
Hadisuyitno, J., Aswin, A. A., Tapriadi, \& Utaminingtyas, S. I. (2017). The Effectiveness Of Snake And Ladder Game To Street Food Safety Knowledge Level At Elementary School Students. IEESE International Journal Of Science And Technology (IJSTE). 6(4): 1-4.

Hamdalah, A. (2013). Efektivitas Media Cerita Bergambar Dan Ular Tangga Dalam Pendidikan Kesehatan Gigi Dan Mulut Siswa Sdn 2 Patrang Kabupaten Jember. Jurnal Promkes.

K.Srinivasan. (2019). Snake And Ladder Games In Cognition Development On Students With Learning Difficulties. Indian Journal Of Dental Advancements.

Lina, H. P. (2017). Perilaku Hidup Bersih Dan Sehat (Phbs) Siswa Di Sdn 42 Korong Gadang Kecamatan Kuranji Padang. Jurnal Promkes, 4(1): 92.

Notoatmodjo, S. (2014). Ilmu Perilaku Kesehatan. Rineka Cipta.

Nurhidayati, A., \& Hilal, N. (2018). Pengaruh Pendidikan Kesehatan Tentang Phbs Dengan Media Permainan Ular Tangga Dan Ceramah Terhadap Pengetahuan Siswa Sd Negeri Limpakuwus Kabupaten Banyumas Tahun 2017. Buletin Keslingmas. Https://Doi.Org/10.31983/Keslingmas.V37i3.38 97

Prasetyanti, D. K., \& Yanuaringsih, G. P. (2019). Pengaruh Permainan Ular Tangga Terhadap Perilaku Hidup Bersih Dan Sehat (Phbs) Pada Anak Sekolah Dasar. Jurnal Penelitian Keperawatan. Https://Doi.Org/10.32660/Jurnal.V5i1.335

Puskesmas Meureubo. (2019). Profil Kesehatan Aceh Barat.

Riskesdas. (2013). Riset Kesehatan Dasar (Riskesdas) 2013. Http://Depkes.Go.Id

Riskesdas. (2018). Hasil Utama Riset Kesehatan Dasar. Http://Depkes.Go.Id

Sari, C. F. (2016). Pengaruh Pendidikan Kesehatan Tentang Cuci Tangan Melalui Media Ular Tangga Terhadap Peningkatan Pengetahuan Anak Usia Prasekolah Di Tk Aba Karangbendo Dan Tk Pertiwi 21 Babadan Banguntapan Bantul Yogyakarta [Stikes Jenderal A. Yani Yogyakarta.]. Http://Repository.Unjaya.Ac.Id/434/ 